\title{
Militarization and Securitization in Africa: The Role of Sino-American Geostrategic Presence
}

\author{
EARL CONTEH-MORGAN*
}

\begin{abstract}
This article is predicated on the argument that the African continent has become a focus of geopolitical and economic attention, especially as a locus of Sino-American rivalry and to some extent cooperation. Accordingly, Sino-American presence in Africa has resulted in: (i) the militarization and securitization of Africa impelled by the war on terrorism and the need to protect vested political and economic interests; (ii) the continent becoming a theater for the interplay of differences between American and Chinese militarization and securitization; and (iii) the inevitable and rare cases of military and security cooperation between the two powers on the continent. The article probes how and why the two powers have militarized and securitized the continent, the activities that constitute militarization and securitization, and prospects for further militarization and securitization in the context of both rivalry and minimal cooperation.
\end{abstract}

\section{Introduction}

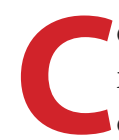

ontrary to the popular consensus that Africa is non-geostrategic, it has nonetheless experienced three "scrambles:" the $19^{\text {th }}$ century scramble for colonies that balkanized it into over 50 states, the ideological Cold War rivalry of the immediate post WWII period, and the current rivalry and focus of China and the United States on the continent along with the presence of other great, middle, and emerging powers. ${ }^{1}$ Indeed, while not as obvious as Sino-American rivalry, other significant powers such as Japan, India, Russia, Turkey, and Iran, among others, are also serious about gaining a strategic foothold on the continent. While the efforts of all of these countries point significantly to Africa's relevance, the Sino-American rivalry and/or cooperation in Africa, in particular, have greatly contributed to the ongoing militarization and securitization of the continent. These two great powers are perennially competing for geopolitical and economic advantages in Africa, defined in terms of natural resources, markets, investment outlets, and political influence within its varied nation-states. ${ }^{2}$ While the competition over Africa by the more powerful states is now mostly over economic influence, the U.S.' need to maintain hegemonic

* University of South Florida, U.S.

Insight Turkey Vol. 21 / No. 1 / 2019, pp. 77-93 
Militarization could be conceptualized as Africa's propensity to attract external military presence as a result of terrorist attacks which threaten the economic interests of the great powers dominance, and China's efforts to ensure its geo-economic interests, have naturally spurred both countries to protect those interests via a robust military presence on the continent. In addition, in an era of growing religious militancy, piracy, and terrorism, both great powers, China and the U.S., are working to ensure the protection of both their African interests and their national security, either in competition or in cooperation with one another on the continent.

The objective of this analysis is to: (i) examine the relationship between increasing terrorist attacks, internal rebellions against incumbent state regimes, incidents of piracy, and the vastly increased American and Chinese military presence in Africa; (ii) analyze the connection between Sino-American geo-economic interests and the deepening militarization and securitization of the African continent; and (iii) discuss differences in the nature of the American and Chinese militarization and securitization of the continent. In other words, in what ways have the two largest economies of the world militarized and securitized Africa? What activities constitute the militarization and securitization of the continent? And perhaps most importantly, why are the U.S. and China militarizing and securitizing the continent?

\section{Conceptual Clarifications and Theoretical Grounding}

The Sino-American militarization of Africa here refers to the increased deployment and accumulation of capabilities -armed forces, arms transfers, and military bases- as a result of factors such as the war on terrorism, piracy, domestic rebellions against incumbent regimes, and a logical need to protect expanding geopolitical and economic interests as part of the quiet and ongoing great-power rivalry on the continent, or as a result of expected great power responsibilities. Militarization is therefore comprised of arms transfers, troop deployment, peacekeeping activities, military engagement against terrorist groups, anti-piracy activities, military training and advising, and the establishment of military bases. ${ }^{3}$ All of these activities are pursued by the two powers in order to have a permanent military presence on the continent.

Militarization takes the form of strengthening African militaries through joint training and combat activities with better-equipped American and Chinese troops in order to forestall or contain terrorist attacks against economic interests. Militarization could, therefore, be conceptualized as Africa's propensity to attract external military presence as a result of terrorist attacks which 
threaten the economic interests of the great powers. It is the deliberate policy of ensuring that African states, in cooperation with American and Chinese troops, develop effective military containment against terrorist attacks which pose a threat to the security of incumbent African regimes and the security of the economic and political interests of foreign powers, including those of the U.S. and China.

In particular, the Copenhagen School on securitization underscores the function of the "speech act" in securitizing an issue. ${ }^{4}$ The securitization of Africa is thus the verbal (oral and written) articulation of the geostrategic importance of Africa to both the U.S. and China. ${ }^{5}$ Such articulation is reflected in policy statements whereby terrorism, rebellion, or violence in Africa have been deemed of such extreme threat to the national security and geo-economic interests of the U.S. and China that they must be contained by and dealt with through military strategy and tactics directed at eliminating the threats. In the case of both the U.S. and China in Africa, the "speech act," i.e. the act of identifying threats to national security, has progressed to the actual setting up of military bases and the deployment of combat troops to ensure the security of their respective geopolitical and economic investments. Moreover, the activities of China in Africa have been articulated by the most recent 2017 National Security Strategy (NSS) of the United States as problems alarming to U.S. national security. ${ }^{6}$ In other words, China's already heavy presence and its growing involvement on the continent have been securitized, i.e. viewed as a "threat to U.S. national security." China's presence and activities on the continent have thus been elevated in the eyes of the West to the level of high politics as opposed to low politics.

China, for its part, has been willing to dilute its longstanding foreign policy of non-interference and add to its involvement in traditional peacekeeping and peacebuilding activities the need to engage in military combat in order to protect its interests in Africa. For China, the threats of terrorism and piracy to its vested interests in Africa have even impelled it to upgrade potential threats from a low political priority concern, to a high political priority concern, hence the need to deploy combat troops and establish its first ever foreign naval base in Djibouti. China's decision in 2013 to deploy combat troops to Mali and to send troops to protect its investments in South Sudan is an indication by China to designate rebel violence and terroristic developments in Africa as a security threat to its geopolitical and economic interest on the continent. ${ }^{7}$ The securitization of Africa is therefore a process that has evolved from foreign policy doctrine and/or speech acts to the implementation of the speech act strategy into practical tactics such as joint military exercises, the establishment of military bases, cooperation in combatting the threat, and ensuring that African militaries become more effective at containing threats to the national security of state actors. 
Both the militarization and securitization of Africa by external actors (the U.S. and China) involve the implementation of verbal (oral or written) military strategies which include troop deployment, cooperation in the armed containment of terrorist groups, the protection of geopolitical and economic interests, and the establishment of military bases designed to produce a climate of stability and security by effectively forestalling threats to internal and external interests. The consequence is the growth and increase of an external military presence in Africa which over time becomes institutionalized. The greater the domestic and external militarization and securitization, the higher the probability of a power struggle between the forces of destabilization -terrorists and rebels- and those of military security promotion -the U.S., China, and incumbent African regimes.

Moreover, it could be argued that militarization and securitization could have negative effects in the form of provoking more terrorist or rebel attacks against the U.S., China, and incumbent African regimes, because of the formers' determination to win the struggle against state actors. This means it is likely that the greater the presence of external economic interests and military presence, the greater will be the frequency of terrorist attacks on countries such as Mali, Chad, Niger, Nigeria, Burkina Faso, and Cote d'Ivoire, among others. The unfolding consequence and/or action-reaction pattern between state actors and terrorist/rebel groups could be represented this way:

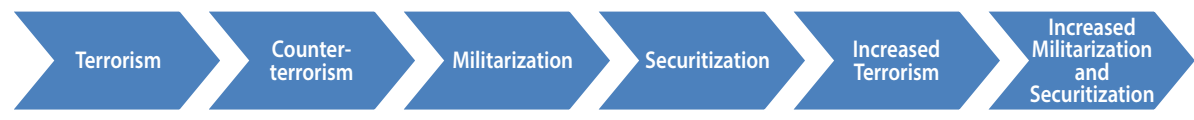

The overall consequence is a never-ending protracted conflict between domestic African regimes and the U.S. and China as external powers viewed as meddling in the internal affairs of the host country.

\section{The U.S. Role in the Militarization and Securitization of Africa}

A primary factor underlying the militarization and securitization of Africa by the world's two economic superpowers is China's phenomenal rise and its profound engagement with African states. The obvious economic Chinese presence on the continent has provoked great power anxiety on the part of the U.S., and is perceived as a challenge to the latter's hegemony on the continent. As great powers, both the U.S. and China are exercising their ability to champion free trade and to guarantee the physical military security of the African states as hosts to their foreign direct investments, sources of raw materials, and even markets for their manufactured goods. China's massive economic power projection in Africa has resulted in a diminished geopolitical and economic gap on the continent between itself and the U.S. in terms of influence. 
China has thereby provoked security anxiety or spatial insecurity on the part of the U.S. where Africa is concerned. It could, therefore, be argued that the U.S.' efforts to militarize and securitize Africa was spawned by China's extensive and deepening presence in Africa. The first response of the U.S. was partly manifested in a U.S. Africa Command (AFRICOM) to ensure a competitive presence instead of a total takeover by China.

The U.S. military presence in Africa is increasing at a rapid rate, even though the U.S. is not engaged in war there, as it was in Afghanistan and Iraq during the 2000s. This growth in U.S. troops on the continent is largely the result of the war on terror. Violent ISIS affiliates active in the Sahel region, such as Boko Haram, al-Shabaab, and al-Qaeda, as well as other extremist groups, are now threatening other regions of the continent and challenging U.S. security interests. According to AFRICOM, in 2017 the U.S. maintained approximately 6,000 troops on active duty on the continent. When contractors are included in this number, the total number of American troops deployed numbered about 75,000 troops. According to General Thomas Waldhauser, head of U.S. AFRICOM, there are currently about 1,800 troops engaged in joint combat missions across 13 nations on the continent. ${ }^{8}$ Most of the troops, over 4,000 military personnel are focused on containing the terrorist group al-Shabaab. The mission in the east African region includes American soldiers on the ground and an increased number of air strikes. ${ }^{9}$ The eastern African region mission is specifically focused on Djibouti, Kenya, and Somalia. In the west of the continent, the focus is on Nigeria, Niger, Chad, and Mali, which comprise a large portion of the Sahel region.

In a way, the militarization and securitization of Africa by the U.S. has had the effect of an American military overstretch caused by persistent and growing terrorist attacks in the east, west, and Sahel regions of Africa. This means that American troops are thinly spread across several countries on a vast continent. U.S. militarization is heavily concentrated in the countries of most security concern such as Somalia, Niger, and Djibouti, the home of AFRICOM. Djibouti, Somalia, and Niger contain the bulk of the roughly 6,000 American servicemen and women spread across the continent.

To a large extent, al-Shabaab poses the greatest security threat to the U.S. in Africa. Allied with ISIS, the group coordinates terrorist attacks directed at neighboring states. As a result, dozens of U.S. strikes are carried out by land, sea, and air against the group operating within Somalia. According to Robyn 


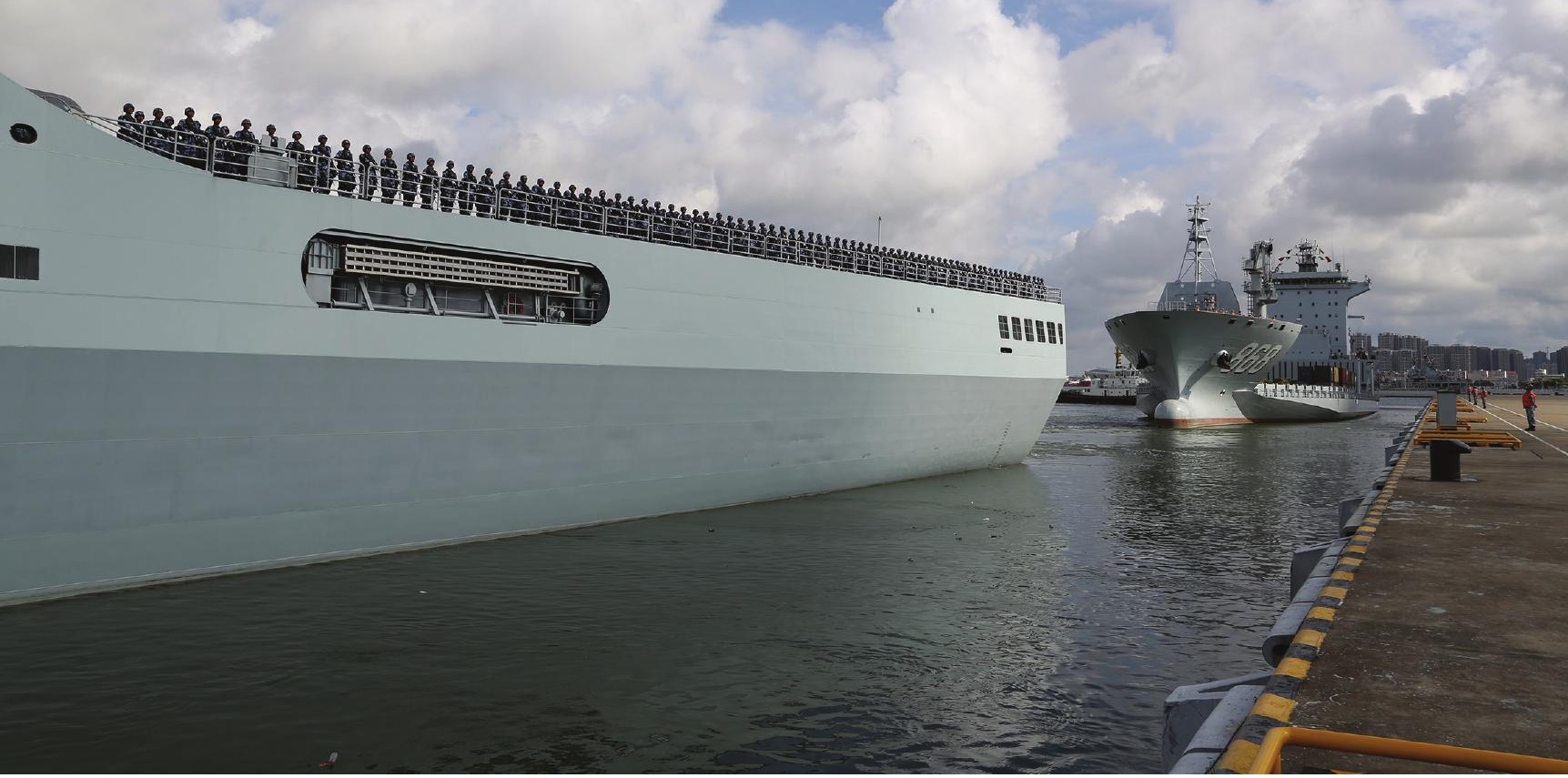

Ships carrying Chinese military personnel depart

from a port in China on July 11,

2017 heading for the People's Liberation Army base in Djibouti,

Africa.

VCG / Getty Images

Mack, a civilian spokesperson for AFRICOM, these military operations are possible because: "We maintain 14 enduring locations: two Forward Sites and 12 Cooperative Security Locations on the African continent, which give the U.S. options in the event of crisis, and enable partner capacity building." ${ }^{10}$ Additionally, the command has designated 20 contingency locations as part of the Theater Posture Plan, which, since 2017 has focused on access to support partners, counter threats, and protect the U.S. interests in east, north, and west Africa. ${ }^{11}$ Although the U.S. military missions are largely to advise, assist, and train African militaries in their efforts to contain Islamist extremists, nonetheless they are always ready for the eventuality of combat in high-threat locations. The U.S. established AFRICOM in 2007 to ensure the cooperation of African states in its war on terrorism and to increase the capabilities of African countries to be able to solve the new and evolving security problem of Islamic terrorism which had erupted in 1998 in Kenya and Tanzania, and which has now become more widespread in all the regions of Africa.

The U.S. military presence in Africa is heavily concentrated in Djibouti's Camp Lemonnier, the permanent U.S. military base. While thinly spread across several countries, the U.S. has a military presence in almost every African country. According to the U.S. Secretary of Defense, James Mattis, the U.S. military presence in Africa is to help Western allies like France build the military and security capacities of African states threatened by and vulnerable to terrorist attacks. ${ }^{12}$ Cooperating with its Western allies and African nations, the U.S. 


\section{China has been taking advantage of Africa's new and vibrant markets by "dumping" many of its goods which African consumers find more affordable than goods from the West}

engages in the defense training of African states such as Mali, Burkina Faso, Niger, Chad, Nigeria, Central African Republic, South Sudan, Ethiopia, Somalia, Kenya, and the Democratic Republic of Congo. With the exception of Djibouti and Uganda, all of the other African nations have between 10 and 80 American troops. ${ }^{13}$ Djibouti is the location for AFRICOM and a major base with roughly 4,000 troops, several aircrafts and numerous drones. Uganda, which has about 300 American troops, is backed by PC-12 surveillance aircraft to search for rebels, especially the Lord's Resistance Army (LRA) rebel group of Joseph Kony. There are also as many as 300 American troops in Cameroon. The functions of these troops are varied and include the search for rebel armies, terrorist groups, and the search for Nigerian school girls kidnapped by Boko Haram. They fly drones over east Africa, provide support for French and African troops in the Sahel, actively engage in intelligence collection, provide advice and training, and protect American citizens and property, among other things.

Ultimately, however, as Grant T. Harris notes, Africa is of security significance to the U.S. for economic reasons. ${ }^{14}$ Unlike the 1980s when Africa was considered almost "hopeless" in terms of economic growth, today Africa has a rapidly growing middle class, and several of its nations enjoy a healthy annual growth rate. The extensive and deepening presence of China in Africa further increases the significance of the continent. China is outpacing the U.S. in terms of seizing economic opportunities in Africa. By June 2017, it was estimated that there were more than 10,000 Chinese firms operating in Africa. ${ }^{15}$ The U.S. is aware of Africa's growing economic importance. The continent is home to a rapidly growing and enterprising middle class, with some countries showing very encouraging growth in GDPs. The U.S. is also aware that China is surpassing it in taking advantage of the best economic opportunities, resulting in Chinese companies being over-represented on the continent. By 2017, China's enterprises in Africa were generating roughly $\$ 180$ billion a year in revenue according to the report by McKinsey and Company Partner. ${ }^{16}$ The continent has become not just a source of energy and other strategic resources, but a huge market for China's affordable goods. The December 2017 National Security Strategy of the United States underscored Africa's growing importance when it stated that: "Africa remains a continent of promise and enduring challenges. Africa maintains many of the world's fastest growing 
While combating terrorism to promote the neo-liberal world order, the U.S. is also concerned about China's role in Africa, which is seen as undermining Africa's march towards a world order favorable to the United States economies, which represent potential new markets for U.S. goods and services. Aspiring partners across the continent are eager to build market-based economies and enhance stability." ${ }^{17}$ China has been taking advantage of Africa's new and vibrant markets by "dumping" many of its goods which African consumers find more affordable than goods from the West.

Second, and related to its economic significance, Africa is of national security importance to China and the U.S. because of its strategic minerals. Africa is home to minerals critical to space and nuclear industries; minerals like vanadium, uranium, or titanium are critical and rare. Africa also possesses minerals that are essential to manufacturing and range from aluminum to zirconium. Since 2005, China has been focused on a very expansive and determined effort to invest heavily in Africa's strategic minerals sector -so much so that the effort was seen as threatening to U.S. national security. This was why in 2005 , China's aggressive push to acquire access to strategic minerals provoked an American national security concern; China was seen as seeking to dominate access to Africa's strategic minerals, possibly with the aim of denying other nations access to these resources. It is not surprising that in the 2006 Report to Congress, the U.S.-China Economic and Security Review Commission emphasized the following: "China's strategy of securing ownership and control of oil and natural gas assets abroad could substantially affect U.S. energy security -reducing the ability of the global petroleum market to ameliorate temporary and limited petroleum supply disruptions in the United States and elsewhere." ${ }^{18}$ China's investments in Africa's oil and other strategic minerals were so extensive that then President George W. Bush considered it a matter vital enough to discuss with then Chinese President Hu Jintao during his April 2006 visit to the White House, while the CIA Director at the time, James Woolsey, described China's strategic resource policy in Africa as a matter of national security.

Perhaps the most important reason for the U.S. militarization and securitization of Africa is to create and maintain a world order favorable to U.S. national interest and predicated on a neo-liberal world order. This theme of a world order favorable to the U.S. is inherent in or implied in virtually all the security strategies of the U.S. over the years. Accordingly, the U.S. combats terrorism in Africa, helps enhance the military security of African states, and even tolerates authoritarian incumbent regimes, because, according to the U.S. National Security Strategy of December 2017: "Many African states are battlegrounds for violent extremism and jihadist terrorists. ISIS, al-Qaeda and their affiliates 
operate on the continent and have increased the lethality of their attacks, expanded into new areas, and targeted U.S. citizens and interests." ${ }^{19}$

The U.S. may not be investing economically in Africa as extensively as China, but it makes sure it has a presence in all African states in the economic, military, and political realms. The presence of AFRICOM, the trade relationship of the African Growth and Opportunity Act (AGOA), the Emergency Plan for AIDS relief, the Power Africa Initiative, and the U.S.-Africa Youth Program, among others, are all initiatives and cooperative efforts aimed at further incorporating Africa into the neo-liberal world order with the aim of strengthening peace, enhancing security, and forging multilateral ties to combat militancy and terrorism. While combating terrorism to promote the neo-liberal world order, the U.S. is also concerned about China's role in Africa, which is seen as undermining Africa's march towards a world order favorable to the United States. This concern is articulated in the U.S. National Security Strategy of 2017 in this way: "China is expanding its economic and military presence in Africa, growing from a small investor in the continent two decades ago into Africa's largest trading partner today. Some Chinese practices undermine Africa's longterm development by corrupting elites, dominating extractive industries, and locking countries into unsustainable and opaque debts and commitments." ${ }^{20}$

\section{China's Role in the Militarization and Securitization of Africa}

Since the mid-2000s, there has been a slow but steady trend towards the militarization and securitization of Africa by China. For well over two decades, China emphasized its non-interference policy, its rhetoric of not mixing business with politics. Until the early 2010s, China focused on playing the role of a responsible rising power in Africa through its focus on multinational peacekeeping and peacebuilding efforts in several countries on the continent. In post-war countries like Liberia, it dispatched post-war reconstruction experts such as military engineers, medical staff, and police training officials. China has been involved in peacekeeping missions in several countries on the continent. However, China seems to have embarked on a more deliberate and focused strategy of militarizing and securitizing Africa along the lines of a forum on China-Africa military and security cooperation. Accordingly, on June 26, 2018, top military officials from 50 African states met in Beijing to launch the first China-Africa Defense and Security Forum. ${ }^{21}$ This forum is significant because it shows China's determination to militarize Africa and elevate it into a top security foreign policy entity. The reality of China's first overseas naval base in Djibouti is already common knowledge, while the launching of this recent defense and security forum aims to deepen military and security ties with the continent. In the recent past, China's involvement in Africa was considered to be solely economic and socio-cultural; now, the Sino-African relationship is 
The expansion of China-Africa military defense and security activities in Africa means that China's engagement in Africa has become even more multidimensional, and is now comprised of economic, political, cultural, educational, and military security and defense activities tilting toward military and security cooperation. To sum up, China's military and security goals in Africa have progressed from United $\mathrm{Na}$ tions Peacekeeping missions to its first overseas military base ever, and located in Africa (Djibouti in 2017), and in 2018 the establishment of a defense and security forum by China’s Ministry of National Defense.

While the U.S. seems to be more involved than China in military and counter-terrorism activities in Africa, according to Lina Benabdal-

lah, China seems to be in the process of trying to extend its activities in the defense and military security area underlined by its win-win, or mutual benefit philosophy. ${ }^{22}$ In addition to conducting joint military exercises and military training for all military officials, China's goal through the forum is to create far stronger military security ties between the People’s Liberation Army, Navy, and Air Force, and African military officers. This decision to increase military and security ties is a realization of President Xi Jinping's promise in 2015 to help Africa establish an "African Standby Force" that would translate into an "African Capacity for Immediate Response to Crisis." During the Forum on China-Africa Cooperation (FOCAC 2015), President Xi Jinping promised $\$ 100$ million in free military aid to the African Union to be used towards this effort. ${ }^{23}$ China's decision to enhance the military and security defense of Africa also entails the holding of military workshops involving tens of thousands of top Chinese and African military officials in China. The current expansion of China-Africa military defense and security activities in Africa means that China's engagement in Africa has become even more multidimensional, and is now comprised of economic, political, cultural, educational, and military security and defense activities.

In terms of military security and defense, China is already known for its involvement in arms sales, anti-piracy training, and the deployment of troops for counter-terrorism. China's militarization of Africa is particularly visible in the area of arms sales to incumbent regimes in African states. While China is not the only country selling arms to Africa, it nonetheless contributes significantly to militarization, especially through the transfer of small arms and light weapons to conflict zones and dictatorial regimes in Africa. Its extensive and comprehensive infrastructural activities in the areas of health, agriculture, media development, railway and road systems, among others, also includes the business of arms sales to incumbent regimes, and at times to both rebel groups 
and governments. Because arms transfer by China to Africa largely consist of Small Arms Light Weapons (SALW), which are inexpensive and easy to use, they have been implicated in ethno-political violence and government-rebel conflicts in countries such as Sudan, South Sudan, the Democratic Republic of Congo, Zimbabwe, and the Central African Republic, among others. China's militarization of the continent via arms transfer is now a reality because of its strategy of making its weapons: (i) affordable/inexpensive; (ii) available for all because of its arms transfer or military relationship with both strategic and non-strategic African countries such as Egypt, South Africa, and Zimbabwe on the one hand, and Eritrea, Equatorial Guinea, Burundi, or Sierra Leone on the other; and (iii) aggressive and effective marketing of both its sophisticated and SALWs in frequent and regular arms exhibits throughout the continent. In other words, China is ever present at arms trade shows in Africa and by 2012 was selling weapons to well over 15 African countries, more than any other major arms exporter. ${ }^{24}$

China's militarization and securitization of Africa is part of its strategy of promoting multi-polarity and/or power dilution directed at the U.S. Accordingly, China securitizes U.S. presence as a way to weaken what China views as a U.S. advantage related to its power preponderance in Africa and other regions of the world. Multi-polarity is a key foreign policy strategy of China, which it pursues in Africa through: (i) extensive and deep economic power projection; (ii) the forging of close economic ties with all African states that adopt the "One China" policy, especially the significant geopolitical and economic states; and (iii) encouraging broad cooperation between Asian and African states, and reviving the Bandung Spirit, and in the case of Africa in particular making FOCAC an integral arm of China's foreign policy and diplomatic strategy aimed at outdoing the U.S. presence on the continent. ${ }^{25}$ Pursuing the three broad objectives outlined above has taken the form of joint economic ventures with African states, political party cooperation, establishing Confucius Centers, aiding Africa's education goals, and more recently deeper cooperation with Africa in matters of military defense and security, among many other development-related activities. China views Africa as a region of high priority to its international relations and that is why it engages in high level diplomacy by embarking on more frequent and regular visits by its heads of states compared to the U.S. In fact, China has now made it a diplomatic tradition for its foreign minister to pay the first international visit of each year to an African state. ${ }^{26}$ Indeed, Chinese heads of state have been accustomed to visiting Africa on a regular basis since the 1960s. The continent is given diplomatic, economic, political, and even military attention above other regions.

China has been particularly forced to flex its military muscle in Africa by the Somali pirates. This has helped to undermine its non-interference policy since 
While many perceive the U.S. and China as rivals in Africa, they actually complement each other's efforts or cooperate to contain transnational threats the mid-2000s when China started combatting piracy in waters near Somalia. Following the repeated hijacking of Chinese vessels by Somali pirates, China deployed three warships to the Gulf of Aden and the Horn of Africa and has since made it a part of its military strategy in the region to protect its merchant vessels from pirates. These anti-piracy activities have helped to reduce hijackings since 2012. The decrease in the frequency of piracy incidents is due to the visible presence of the Chinese People's Liberation Army Navy (PLAN). This is in line with China's establishment of its first overseas naval facility in Djibouti with the objective of using it as a logistical forward base to supply the anti-piracy operations of PLAN. In April 2017, PLAN was able to adequately respond to a distress call from a ship in the Gulf of Aden that had been attacked by pirates. ${ }^{27}$

Since the early 1960s, China has considered Africa to be of geostrategic importance to its rivalry with the two superpowers of that era, the U.S. and the Soviet Union. Now with its extensive and deep geopolitical, economic and socio-cultural engagement with the continent, it is impelled to defend and protect: (i) the physical security of its investments and nationals who now number roughly a million; (ii) defend itself from politically motivated attacks because of the reality or perception by rebels and terrorists that it is supporting incumbent despotic regimes; and (iii) violent protests against China by African workers related to labor disputes and/or commercial insecurity caused by the large inflow of Chinese goods which undercut the profits of African business owners. In addressing all of these security threats, China cooperates when necessary with either the African Union or the United Nations, or adopts a defensive, unilateral approach.

\section{Sino-American Military and Security Cooperation in Africa}

While the U.S. and China may be perceived as rivals for access to energy sources and political influence, they at the same time cooperate to resolve each other's security concerns through their military presence and engagement with African states. This cooperation helps contain terrorist violence and make possible the uninterrupted flow of both oil and other strategic resources of value to both of them. Countries like Nigeria, São Tomé and Principe, Angola, Gabon, the Democratic Republic of Congo, South Africa, and the like, are of geo-economic significance to both countries. Their extensive presence in the continent and security concerns over the uninterrupted flow of strategic resources has increased the militarization and securitization of the continent. 


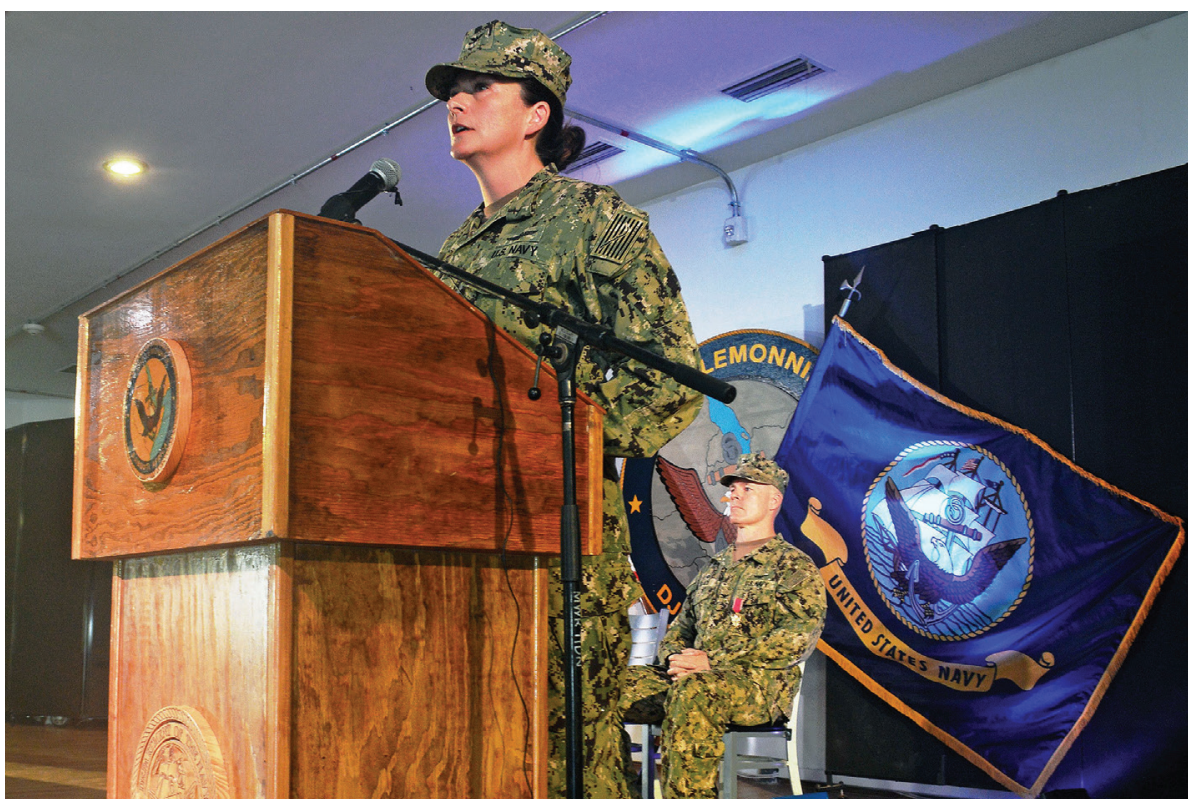

Moreover, while many perceive the U.S. and China as rivals in Africa, they actually complement each other's efforts or cooperate to contain transnational threats. The continent has now become plagued by the terrorist affiliates of ISIS and al-Qaeda, and by rebel violence in some countries that are rich in minerals like South Sudan, the Democratic Republic of Congo, and Nigeria. The Sino-American ongoing militarization of the continent and support for incumbent regimes helps ensure some stability. There is, of course, the possibility that their presence could provoke violence against incumbent regimes. China, in particular, has been at the forefront of combating piracy to ensure the free flow of resources and vessels through the Gulf of Aden and the Horn of Africa. The motivation for the U.S.-China security cooperation in Africa is the fact that both countries have extensive economic interests in the country that require efforts to promote peace and security in specific African countries and on the continent as a whole. Both nations are threatened in Africa by terrorism and rebellions against incumbent regimes, by piracy in the Gulf of Aden and the Horn of Africa, and by other criminal threats which also impact the economic, and overall national interests of both countries. Accordingly, the need to protect their vested interests in the continent leads the U.S. and China to bilateral cooperation in the areas of peace and security, in particular through UN peacekeeping and anti-piracy efforts. ${ }^{28}$

While a U.S.-China rivalry is alluded to in rhetoric between the two nations regarding their presence in Africa, nonetheless both are also involved in multilateral collaboration on the continent in the areas of peacekeeping. While
U.S. Captain Nancy S. Lacore delivers a speech during a handover ceremony at the Camp Lemonier Navy base in Djibouti on July 20, 2017. 
What used to be a Sino-African relationship solely emphasizing business and socio-cultural cooperation has now evolved to include military and security concerns, policies, goals, and activities because of the new reality: the need to protect economic investments from rebels and terrorist groups

the U.S. does not contribute troops to UN multilateral peacekeeping in Africa, it is nonetheless the largest contributor (28 percent) of the UN peacekeeping annual budget of roughly $\$ 8.2$ billion. ${ }^{29}$ China, on the other hand, contributes more troops to peacekeeping than all the other permanent members of the UN. Moreover, China has graduated from merely contributing UN peacekeepers to sending combat troops to the UN Multidimensional Integrated Stabilization Mission in Mali (MINUSMA), and deploying combat troops to the UN Mission in the Republic of South Sudan (UNMISS). China's President Xi Jinping has often expressed China's willingness to increase its involvement in peacekeeping activities in Africa and even to spearhead the new UN peacekeeping capability readiness system; it has therefore recently established a permanent peacekeeping police squad -a peacekeeping readiness force of about 8,000 troops. ${ }^{30}$ As part of their bilateral cooperation on Africa, the two countries operate within the U.S.-China consultation on African affairs which takes place between the U.S. State Department and the Chinese Ministry of Foreign Affairs. By 2016, they had conducted seven of such cooperative talks, which are usually jointly chaired by the U.S. Assistant Secretary of State for African affairs and the Chinese Vice Minister for Foreign Affairs. Areas of cooperation on Africa between the U.S. and China cover communication and information exchange, security collaboration in the field of counter-piracy, including anti-piracy exercises in the Gulf of Aden and the Horn of Africa. These areas of cooperation focus on enhancing the two countries' collective strength and presence on the continent.

\section{Summary and Conclusions}

Since China is now heavily engaged in Africa, its longstanding policy posture on security and non-interference is adapting to new realities. Its economic investments are extensive and well-entrenched, and in several countries have become targets for rebels challenging the incumbent regimes (the Democratic Republic of Congo, South Sudan, Nigeria, etc.). It is therefore not surprising that by the early 2010s China was deploying combat troops to provide security for its factories, plants, mines, and energy investments. This means that China is now steadily adapting to new realities and abandoning a purely non-interference foreign policy posture in favor of a flexible one that does not preclude 
the use of force when necessary. What used to be a Sino-African relationship solely emphasizing business and socio-cultural cooperation has now evolved to include military and security concerns, policies, goals, and activities because of the new reality: the need to protect economic investments from rebels and terrorist groups.

The United States and China in Africa have ignited the continuing militarization and securitization of Africa because of their huge investments and geopolitical commitments to combat rebellion and piracy. An action-reaction pattern between these two powers and forces of destabilization may have been set in motion because the very presence of external troop deployment and military technology could result in emboldening and increasing the determination of rebels and terrorists to fight an unrelenting battle against what they consider external intervention. The establishment of cooperative military security locations, forward military operating sites, drone bases, and even AFRICOM in Djibouti could act as a motivating factor for terrorist attacks on incumbent regimes and the external economic interests of the two powers. Both China and the U.S. are susceptible to similar security concerns that impel them to cooperate in containing them. Both have a common interest in containing terrorism, international crime, narco-terrorism, and piracy to prevent these threats from destabilizing their interests in Africa, and their own domestic interests. Both countries have of late considered Africa to be of high priority due to its strategic resource endowment and its tendency to be a magnet for terrorist activity with both national and international dimensions.

As China's interests become more extensive in Africa, it will find itself more open to security cooperation with the United States. However, China's almost sacrosanct non-interference policy presents a dilemma for the nation in its cooperative efforts with the U.S. in particular and the West in general. For instance, China prefers unilateral anti-piracy escort missions compared to multilateral missions because it is wary of being trapped into the modus operandi or agendas of the U.S. and other Western countries. Although China has engaged in combat troop deployment in Mali, it is nonetheless very reluctant to adopt an offensive military deployment posture in Africa. Its anti-piracy and military deployment strategies have remained largely defensive and protective. This defensive overseas military posture has been shaped by its non-interference policy and is likely to continue shaping its militarization and security policy in Africa. This policy differs from that of the U.S. which adopts more of an offensive and proactive strategy in combating terrorism in Africa.

In sum, the current geopolitical and economic importance of the African continent has resulted in attracting the attention of the world's two largest economic powers. This Sino-American attention and presence in the continent has resulted in: (i) competing militarization manifested in the establishment of military bases and deployment of troops by both powers to ensure stability; 
(ii) regular policy pronouncements underscoring the security importance of Africa to both powers' national security concerns; and (iii) a growing security and military cooperation along with rivalry on matters related to containing terrorism and protecting their interests in the continent.

\section{Endnotes}

1. See, for example, Lee Wengraff, "China vs. the U.S.: The New Imperial Scramble for Africa," Red Pepper, (May 23, 2018), retrieved from https:// www.redpepper.org.uk/china-vs-the-us-the-new-imperialscramble-for-africa/.

2. Zhao Hong, "China-U.S. Oil Rivalry in Africa," Copenhagen Journal of Asian Studies, Vol. 26, No. 2 (2008), retrieved from https://rauli.cbs.dk/index.php/cjas/article/viewFile/2240/2420.

3. See, Ulrich Albrecht, "Technology and Militarization of Third World Countries in Theoretical Perspectives," Bulletin of Peace Proposals, Vol. 8. No. 2 (1977), pp.124-126.

4. For more details on securitization by the Copenhagen School, see, Holger Stritzel, Securitization Theory and the Copenhagen School, (London: Palgrave, 2014); Rita Taureck, "Securitisation Theory and Securitization Studies," Journal of International Relations and Development, Vol. 9, (2006), pp. 53-61; Roxanna Sjostedt, "Securitization Theory and Foreign Policy Analysis," in Cameron Thies (ed.) Oxford Research Encyclopedias, (Oxford: Oxford University Press, 2017).

5. On securitization, see for example, Thierry Balzacq, "Three Faces of Securitization: Political Agency, Audience and Context," European Journal of International Relations,"Vol. 11, No. 2 (2005), pp. 171-201.

6. "National Security Strategy of the United States of America," The White House, (December 2017), retrieved from https://www.whitehouse.gov/wp-content/uploads/2017/12/NSS-Final-12-18-2017-0905. pdf.

7. See, Kevin Knodell, "China Is Sending Combat Troops to Africa," War Is Boring, (June 1, 2014), retrieved from https://warisboring.com/china-is-sending-combat-troops-to-africa/.

8. Alexa Liautaud, "U.S. Military Presence in Africa Grew Again, but "We're Not at War"Top U.S. Command Says," Vice News, (March 6, 2018), retrieved from https://news.vice.com/en_us/article/j5b3pb/us-military-presence-in-africa-grew-agin-but-were-not-at-war-top-us-commander-says.

9. For more details, see, Les Neuhaus, "The U.S. Military Stretched Thin in 50 African Nations," The Observer, (December 1, 2017), retrieved from https://observer.com/2017/12/us-military-has-presence-in 50-of-54-african-countries/; Greg Myre, "The U.S. Military in Africa: A Discreet Presence in Many Places," National Public Radio, (October 20, 2017), retrieved from https://www.npr.org/sections/thetwo-way/2017/10/20/558757043/the-u-s-military-in-africa-a-discreet-presence-in-many-places.

10. As quoted in Neuhaus, "U.S. Military Stretched Thin in 50 African Nations."

11. See, Eric Schewe, "Why Is the U.S. Military Occupying Bases Across Africa?" JSTOR Daily, (April 11, 2018), retrieved from https://daily.jstor.org/why-is-the-u-s-military-occupying-bases-across-africa/.

12. Kathryn Watson, "Where Does the U.S. Have Troops in Africa, and Why?" CBS News, (October 23, 2017), retrieved from https://www.cbsnews.com/news/where-does-the-u-s-have-troops-in-africa-and-why/.

13. Watson, "Where Does the U.S. have Troops in Africa, and Why?"

14. Grant T. Harris, "Why Africa Matters to U.S. National Security," Atlantic Council, (May 25, 2017), retrieved from https://www.atlanticcouncil.org/publications/reports/why-africa-matters-to-us-national-security.

15. Some China-Africa experts challenge these economic figures. See, for example, Doug Tsuruoka, "How Many 'Chinese' Businesses Are in Africa?" Asia Times, (March 16, 2018), retrieved from www.atimes. com/article/many-chinese-businesses-africa/.

16. Irene Yuan Sun, Kartik Jayaram, and Omid Kassiri, "Dance of the Lions and Dragons: How Are Africa and China Engaging, and How Will the Partnership Evolve?" Mckinsey \& Company, (June 2017), retrieved 
from https://www.mckinsey.com/featured-insights/middle-east-and-africa/the-closest-look-yet-at-chinese-economic-engagement-in-africa.

17. "National Security Strategy of the United States," p. 52.

18. "Report to Congress of the U.S.-China Economic and Security Review Commission," U.S.-China Economic and Security Review Commission, (November 2006), retrieved from https://www.uscc.gov/sites/ default/files/annual_reports/USCC\%20Annual\%20Report\%202006.pdf.

19. "Report to Congress of the U.S.-China Economic and Security Review Commission."

20. "Report to Congress of the U.S.-China Economic and Security Review Commission."

21. See, Yun Sun, "U.S.-China Cooperation on African Security," Brookings, (November 1, 2016), retrieved from https://www.brookings.edu/blog/africa-in-focus/2016/11/01/us-china-cooperation-on-africansecurity/.

22. Lina Benabdallah, "China-Africa Military Ties Have Deepened. Here Are 4 Things to Know," The Washington Post, (July 6, 2018), retrieved from https://www.washingtonpost.com/news/monkey-cage/ $\mathrm{wp} / 2018 / 07 / 06 /$ china-africa-military-ties-have-deepened-here-are-4-things-to-know/?utm_term=.0fda19c5de3f.

23. See, Kai Xue, "FOCAC 2015: Making Sense of the Numbers," The China Africa Project, (December 30, 2015), retrieved from https://chinaafricaproject.com/focac-2015-making-sense-of-the-numbers/; Yun Sun, "Xi and the $6^{\text {th }}$ Forum on China-Africa Cooperation: Major Commitments, But with Questions," Brookings, (December 7, 2015), retrieved from https://www.brookings.edu/blog/africa-in-focus/2015/12/07/ xi-and-the-6th-forum-on-china-africa-cooperation-major-commitments-but-with-questions/.

24. Column Lynch, "China's Arms Exports Flooding Sub-Saharan Africa," The Washington Post, (August 25, 2015), retrieved from https://www.washingtonpost.com/world/national-security/chinas-arms-exports-flooding-sub-saharan-africa/2012/08/25/16267b68-e7f1-11e1-936a-b801f1abab19_story.html?utm_term=.fd0707b045a2.

25. See, Earl Conteh-Morgan, The Sino-African Partnership: A Geopolitical Economy Approach, (New York: Peter Lang, 2018).

26. See, Eric Biegen, "Why Foreign Minister Wang Yi's Africa Tour Is Crucial," China Plus, (January 13, 2018), retrieved from http://chinaplus.cri.cn/opinion/opedblog/23/20180113/77514.html.

27. Ankit Panda, "As Somali Pirates Return, Chinese Navy Boasts of Anti-Piracy Operations," The Diplomat, (April 16, 2017), retrieved from https://thediplomat.com/2017/04/as-somali-pirates-return-chinese-navy-boasts-of-anti-piracy-operations/.

28. Yun," U.S.-China Cooperation on African Security."

29. Yun, "U.S.-China Cooperation on African Security."

30. Michael Martina and David Brunstrom, “China's Xi Says to Commit 8,000 Troops for U.N. Peacekeeping Force," Reuters, (September 28, 2015), retrieved from https://www.reuters.com/article/us-un-assemblychina/chinas-xi-says-to-commit-8000-troops-for-u-n-peacekeeping-force-idUSKCNORS1Z120150929; "China Registers 8,000 Standby Peacekeepers at UN," XinhuaNet, (September 18, 2018), retrieved from www.xinhuanet.com/english/2017-09/28/c-136645953.htm. 


\section{EUROPEAN \\ ISLAMOPHOBIA \\ REPORT 2017}

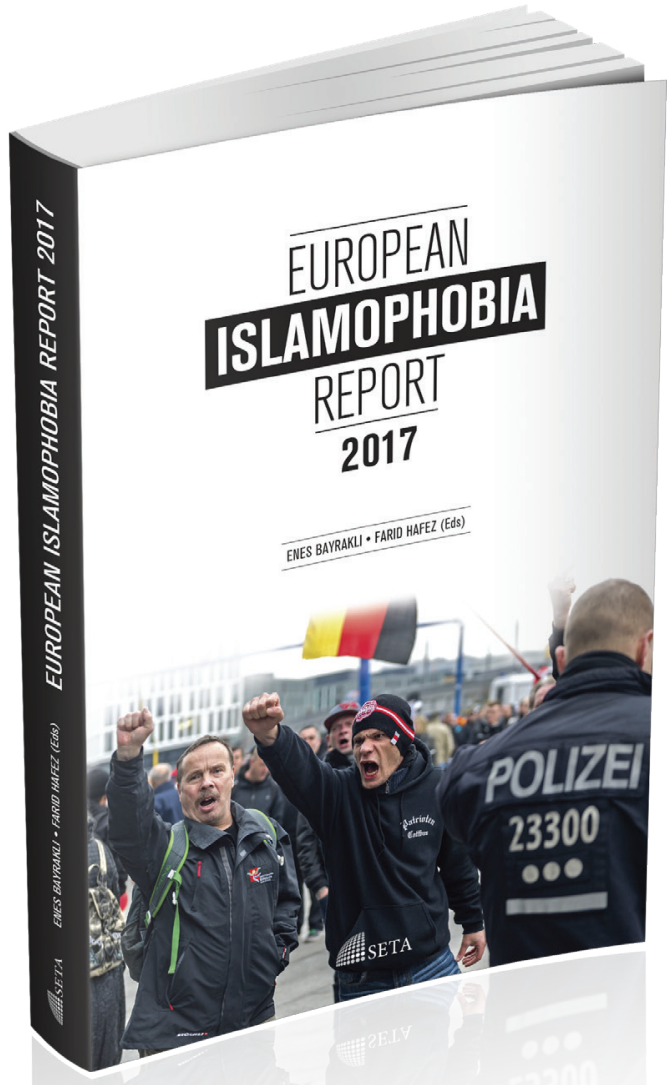

By ENES BAYRAKLI • FARID HAFEZ (Eds.)

The third annual European Islamophobia Report (EIR) scrutinizes the developments of Islamophobia in 33 European countries for 2017
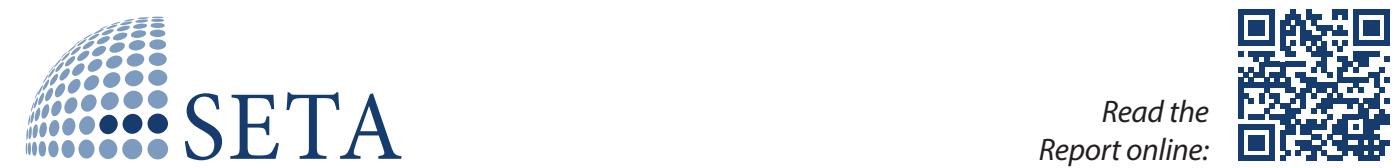